\title{
Ecology of Heterotrophic Microflagellates. II. Bioenergetics and Growth
}

\author{
T. Fenchel \\ Department of Ecology and Genetics, University of Aarhus, Ny Munkegade, DK-8000 Aarhus C, Denmark
}

\begin{abstract}
The bioenergetics of growth of 6 species of heterotrophic (bacterivorous) microflagellates was studied in batch cultures. Maximum growth rates varied between 0.15 and $0.25 \mathrm{~h}^{-1}$ among the species, but growth as slow as $0.028 \mathrm{~h}^{-1}$ could be maintained. Yield (gross growth efficiency) was found to be ca. $30 \%$ (volume) or, in 2 cases, 34 and $43 \%$ (C basis) respectively; net growth efficiency (C) was $60 \%$. Respiratory and growth rates were directly proportional to consumption rate within the range of growth rates studied. Clearance (volume of water cleared for bacteria per unit time and measured in fractions of cell volume) ranged from about $5 \times 10^{4}$ to about $10^{6} \mathrm{~h}^{-1}$; this large variation can in part be explained as a consequence of specialization to different food particle sizes. In general, the parameter values suggest that the type of flagellates studied may grow on and possibly control the concentration of bacteria found in marine plankton.
\end{abstract}

\section{Introduction}

Several authors have credited importance to the omnipresent heterotrophic microflagellates for the carbon cycle of aquatic environments, in particular as consumers of suspended bacteria (Pomeroy and Johannes, 1968; Lighthart, 1969; Chretiennot, 1974; Sorokin, 1977; Haas and Webb, 1979; Sieburth, 1979). Bacteria are now know to comprise a dynamic pool of organic carbon in the sea, yet no grazing organisms have so far convincingly been shown to be capable of keeping bacterial densities within the range of 0.5 to $2 \times 10^{6}$ $\mathrm{ml}^{-1}$ which is typical for marine plankton (Ferguson and Rublee, 1976; Hoppe, 1976; Hagström et al., 1979). In order to evaluate the role of the microflagellates, it is necessary not only to quantify them in nature, but also to obtain a qualitative and quantitative understanding of their biology, food uptake and bioenergetics. The present paper quantifies their ability to concentrate food particles (clearance) and other bioenergetic parameters with special reference to balanced growth for 6 different types of microflagellates. No such data have previously been provided for these smallest phagotrophs. Other papers (Fenchel, $1982 \mathrm{a}, \mathrm{b}, \mathrm{c}$ ) treat functional morphology, adaptation to environmental heterogeneity, and quantitative occurrence in a marine environment.

\section{MATERIALS AND METHODS}

\section{Material}

Of the 6 species studied, 4 are marine (choanoflagellate Monosiga sp., non-pigmented chrysomonad Paraphysomonas vestita (Stokes), bicoecid Pseudobodo tremulans Griessmann, helioflagellid Actinomonas mirabilis Kent, and 2 are limnic (chrysomonad Ochromonas sp., kinetoplastid Pleuromonas jaculans Perty). A description of the species including information on their origin, isolation and maintenance in cultures is given in Fenchel (1982 a).

\section{Experimental Methods}

The basic experimental technique was the measurement of growth rates and of cell yield in batch cultures with a known initial concentration of a single species of food bacteria. Each culture was started in $50 \mathrm{ml}$ of culture medium in $150 \mathrm{ml}$ Erlenmeyer flasks. For marine flagellates the medium consisted of aged, filtered $(0.2 \mu \mathrm{m})$ seawater $(25 \% \mathrm{~S})$; for limnic forms a solution of $\mathrm{NaCl}(80 \mathrm{mg}), \mathrm{NaHCO}_{3}(4 \mathrm{mg}), \mathrm{KCl}(4 \mathrm{mg})$, and $\mathrm{CaCl}_{2} 6 \mathrm{H}_{2} \mathrm{O}(8 \mathrm{mg})$ in $1 \mathrm{l}$ glass distilled $\mathrm{H}_{2} \mathrm{O}$. As food bacteria, 2 species of Pseudomonas, isolated from 
seawater and from pond water, respectively were used. They were grown on nutrient agar plates. Both forms are rods which measure about $1.3 \times 0.75 \mu \mathrm{m}$ (volume: $0.6 \mu^{3}$ ) and contain about $10^{-10} \mathrm{mg} C$ per cell. The marine form is motile, the freshwater one is not. For use, the bacteria were scraped from 3 to $4 \mathrm{~d}$ old cultures, suspended in sterile water and added to the culture flasks in final concentrations ranging from $10^{6}$ to $2 \times 10^{8} \mathrm{ml}^{-1}$. Controls showed that the bacteria do not multiply in the media used and that the respiratory rate of the starved bacteria is quite low so that the decrease in nutritional value during an experiment would not be significant. Suspensions of flagellates were then finally added to give initial concentrations in the range of $10^{2}$ to $10^{3} \mathrm{ml}^{-1}$. Cultures were kept without shaking (shaking was tried, but did not alter the results) in the dark at $20^{\circ} \mathrm{C}$; all rates and other parameter values in this paper refer to this temperature.

After inoculation, bacteria and flagellates were counted every fourth hour until all bacteria had been consumed and multiplication of the flagellates had stopped (usually after 60 to $80 \mathrm{~h}$ depending on initial concentrations). Counting of prey and predator organisms were carried out on the same samples with fluorescence microscopy following Hobbie et al. (1977). The culture flasks were shaken and $1 \mathrm{ml}$ was removed and mixed with an isotonic solution of formaldehycle and acridine orange to give final concentrations of about 4 and $0.01 \%$ respectively. The fixed sample was then filtered through an $0.2 \mu \mathrm{m}$ Nuclepore filter stained with irgalan black. The number of organisms on the filter was then estimated with an epifluorescence microscope fitted with an ocular grid and using blue light. Ideally about 200 cells (bacteria as well as flagellates) were counted for each data point, but this could not always be achieved in the beginning (flagellates) or the end (bacteria) of an experiment. In a few experiments, bacteria were quantified spectrophotometrically (at $660 \mathrm{~nm}$ ) and the flagellates were counted in a haemocytometer.

Flagellate volumes were estimated from linear dimensions of formaldehyde-fixed cells assuming a spherical shape or, in the case of Pleuromonas jaculans, and of swarmers of Monosiga sp. and Pseudobodo tremulans, ellipsoids. Carbon content of bacteria and flagellates was measured in concentrated suspensions with known cell numbers using wet oxidation with chromic-sulfuric acid according to Strickland and Parsons (1965). Respiratory rates were measured as the decrease in oxygen tension in cell suspensions in $25 \mathrm{ml}$ glass stoppered bottles without a gas phase. Each bottle contained a glass bead which allows regular stirring. At 20 or 40 min interval and for 2 or $3 \mathrm{~h}$, a $200 \mu \mathrm{l}$ sample was removed with a capillary pipette and replaced with sterile water. The oxygen tension of the sample was measured with a Radiometer oxygenmeter and the $\mathrm{O}_{2}$ concentration calculated from salin-

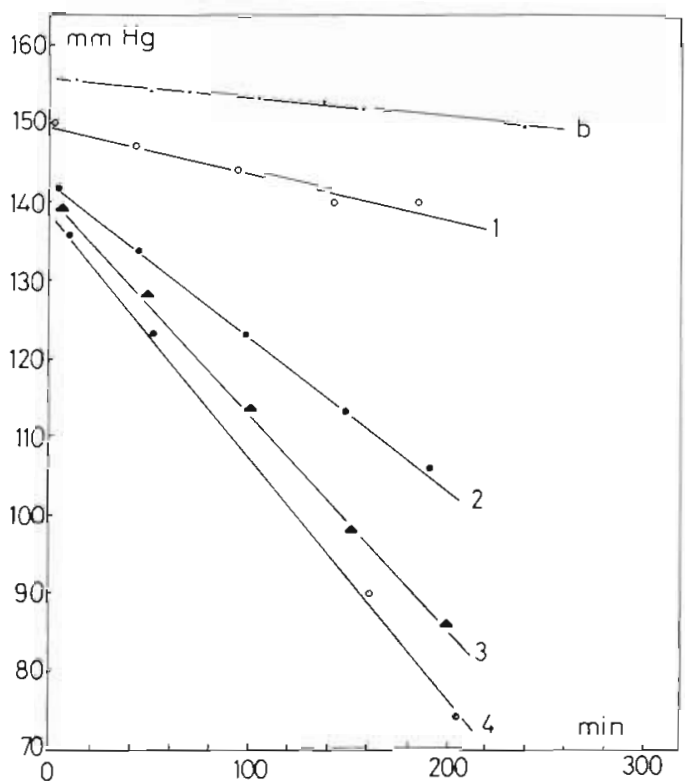

Fig. 1. Decrease of $\mathrm{O}_{2}$ pressure in incubations with about $3.5 \times 10^{5}$ Ochromonas sp. $\mathrm{ml}^{-1}(1-4)$. After 34 h of starvation the cells were transferred to different concentrations of bacterial suspensions and after a further $2 \mathrm{~h}(\mathrm{t}=\mathrm{O}) \mathrm{O}_{2}$ uptake was measured. b: bacterial control: $9.8 \times 10^{7}$ bacteria $\mathrm{ml}^{-1}$; 1 : no bacteria added; $2: 3.5 \times 10^{7}$ bacteria $\mathrm{ml}^{-1} ; 3: 7.0 \times 10^{7}$ bacteria $\mathrm{ml}^{-1} ; 4: 1.4 \times 10^{8}$ bacteria $\mathrm{ml}^{-1}$

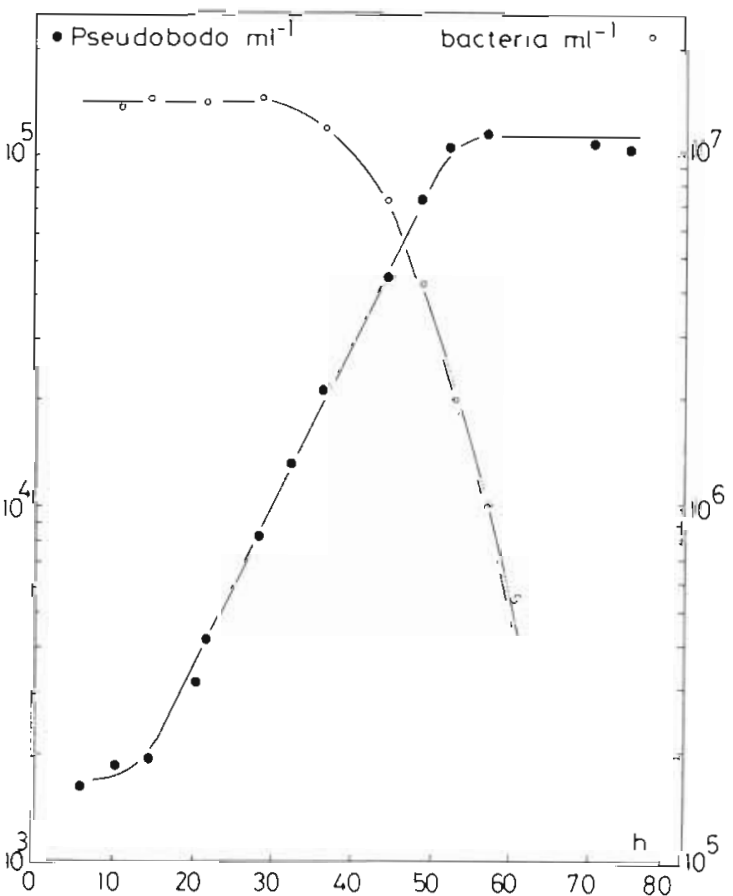

Fig. 2. Pseudobodo tremulans. Batch culture initiated with $1.2 \times 10^{7}$ bacteria $\mathrm{ml}^{-1}$ 
ity and temperature $\left(20^{\circ} \mathrm{C}\right)$. From the linear decline in oxygen concentration and from cell numbers, $\mathrm{O}_{2}$ uptake per cell was calculated. It was necessary to measure the respiration of growing flagellates and so the presence of bacteria in the flasks could not be avoided. Initially, heat- or radiation-inactivated bacteria were used. However, the respiratory rate of starved bacteria was so low (Fig. 1) that no serious error could be introduced by including live bacteria of known concentration and then correcting for bacterial respiration based on a control experiment containing only bacteria.

\section{Calculation of Parameters from Growth Experiments}

In principle, organisms never attain balanced growth in a batch culture since the environment is continously changed and food resources continously removed. In practice, however, it was possible to follow the flagellates for at least 4 to 5 generations of exponential growth during which bacterial numbers decreased only slightly and flagellate cell volume remained constant (Figs. 2 and 3). Such growth curves

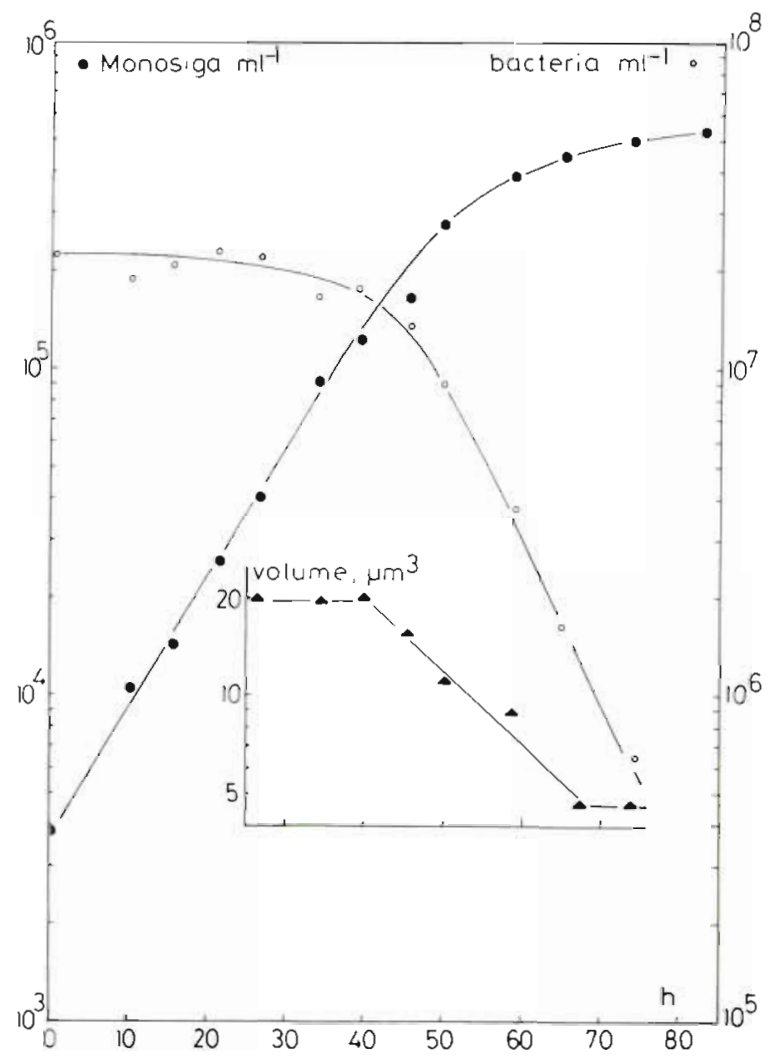

Fig. 3. Monosiga sp. Batch culture initiated with $1.25 \times 10^{7}$ bacteria $\mathrm{ml}^{-1}$. Insertion: average flagellate volume for the last $50 \mathrm{~h}$ of experiment. Onset of starvation leads to 2 successive divisions without growth can be considered as very close approximations to steady-state conditions in a continuous culture. Eventually, of course, all bacteria will be consumed and flagellate growth declines to zero. The batch cultures therefore give 2 kinds of information: a growth rate constant $\mu(x)$ and the eventual cell yield $Y$ as functions of the initial prey density $x$. The growth rates can be fitted to a hyperbolic function of the form of MichaelisMenten kinetics: $\mu(x)=\mu_{m} x /(x+K)$, where $\mu_{m}$ maximum growth rate asymptotically approached at high prey densities; $\mathrm{K}=$ a half-saturation constant (Figs. 4 to 6). The reason for this relationship will be rationalized below.

Although cannibalism was observed microscopically for Ochromonas sp., a large number of growth experiments using different sized flagellate inoculates shows that growth rates only depended on bacterial concentrations, but not on flagellate densities within the range occurring in the cultures. Higher order interactions such as shown in Tetrahymena pyriformis cultures by Curds and Cockburn $(1968,1971)$ could be ignored in the present study.

In principle, bacterial consumption per predator could be estimated directly from curves such as shown

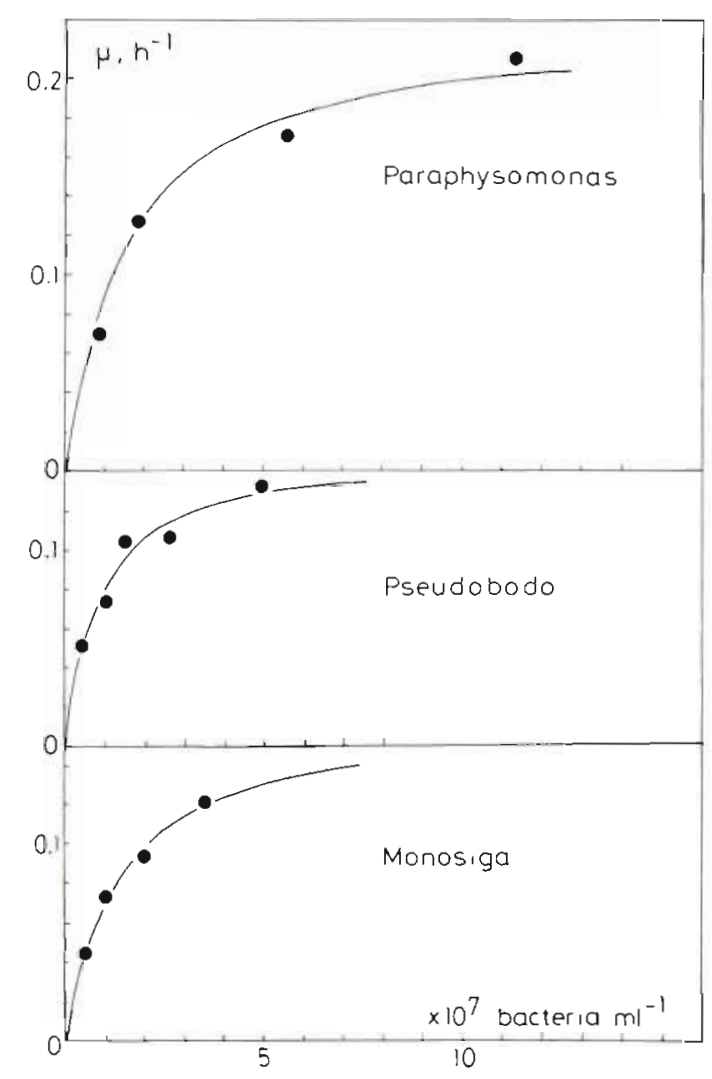

Fig. 4. Growth rates as function of bacterial concentrations in 3 flagellate species 
in Figs. 2 and 3. However, due to the dynamics of the system this approach will give a high statistical error. Instead the following considerations were applied. The cell yield is nearly invariant with growth rate and linearly related to the initial number of bacteria (Figs. 7 and 8 ). It is further assumed that the bacterial uptake per flagellate per unit time, $U(x)$, is also a hyperbolic function of $x$ of the form: $U(x)=U_{m} x /(x+K)$. This is rationalized as in Fenchel $(1980$ a). The consumption rate is limited by 2 processes. At very high prey concentrations it is limited by the time taken to phagocytize 1 bacterium and during which another bacterium cannot be engulfed. This is $U_{m}^{-1}$ (dimension: $\mathrm{T}$ ) and so $U_{m}$ measures the maximum rate at which prey can be swallowed. The other process is the concentration of food particles from the environment. This depends on the velocity of feeding currents, the geometry of the cells feeding organelles and the size and shape of the food particles but is assumed to be invariant with food particle concentration. Letting $x \rightarrow O$ in the expression for $U(x)$, it can be seen that at low particle concentrations (phagocytosis rate is not limiting), $U(x)=F_{m 2} x$, where $F_{m}=U_{m} / K$ (dimension $L^{3} T^{-1}$ ) is the maximum clearance, that is the volume of water the organism can clear for food particles per unit time. Clearance is the most meaningful measure of the importance and competitive ability of an organism as grazer of suspended particles in nature.

From these considerations it is clear that $U=\mu / Y$. Furthermore, from the growth experiments $\mu_{\mathrm{m}}$ and $K$ can be estimated (by linear regression of a reciprocal plot of $\mu$ vs. $x$ ) and consequently $U_{m}$ and $F_{m}$ can be calculated. In practice the yield constant $Y$, when expressed as numbers of flagellates per bacterium and measured in batch cultures, will have to be corrected. This is because after the prey bacteria have been nearly totally consumed, the flagellates will still on the average undergo 1 (Ochromonas sp., Paraphysomonas vestita, Pleuromonas jaculans, Actinomonas mirabilis) or 2 (Monosiga sp., Pseudobodo tremulans) fissions leading to cells which are on the average 2 , respectively 4 times smaller than the growing cells (Fig. 3; for discussion on the phenomenon, see Fenchel, 1982 a, b). Values of $Y$ as read from graphs like Figs. 7 and 8 must be divided by 2 or 4 in order to arrive at the correct estimates of $U_{m}$

\section{RESULTS}

Exponential growth rates as function of bacterial density could in all cases be fitted to a MichaelisMenten form equation (Figs. 4 to 6). Within the same range of growth rates, cell yields were nearly constant (Figs. 7 to 8 ). Cells grown exponentially for several

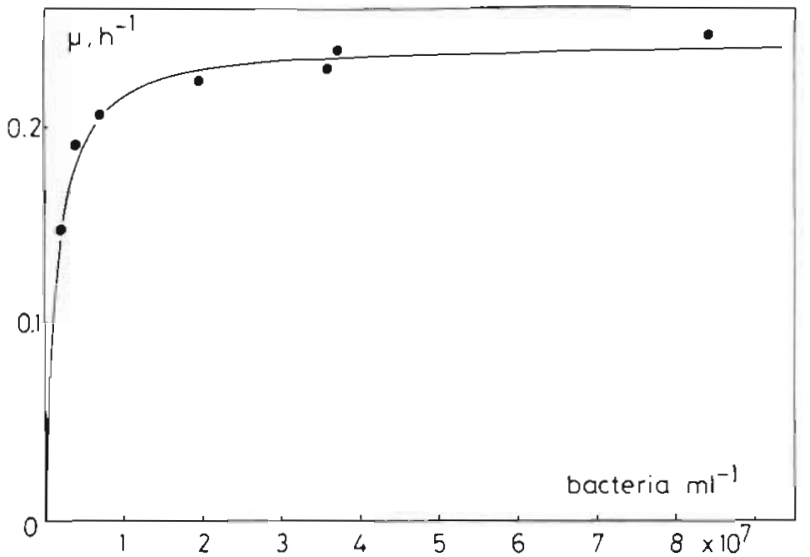

Fig. 5. Actinomonas mirabilis. Growth rate as function of bacterial concentration

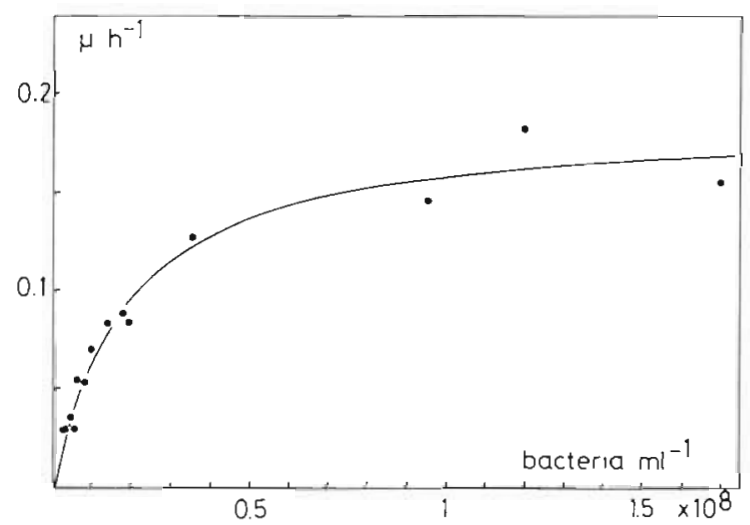

Fig. 6. Ochromonas sp. Growth rate as function of bacterial concentration

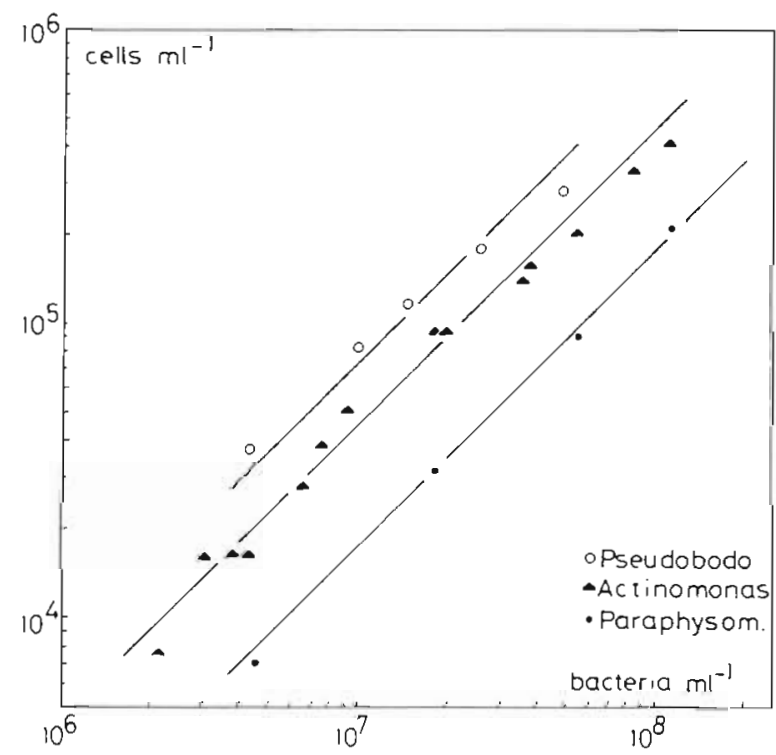

Fig. 7. Cell yield as function of initial bacterial concentration in 3 species of flagellates 


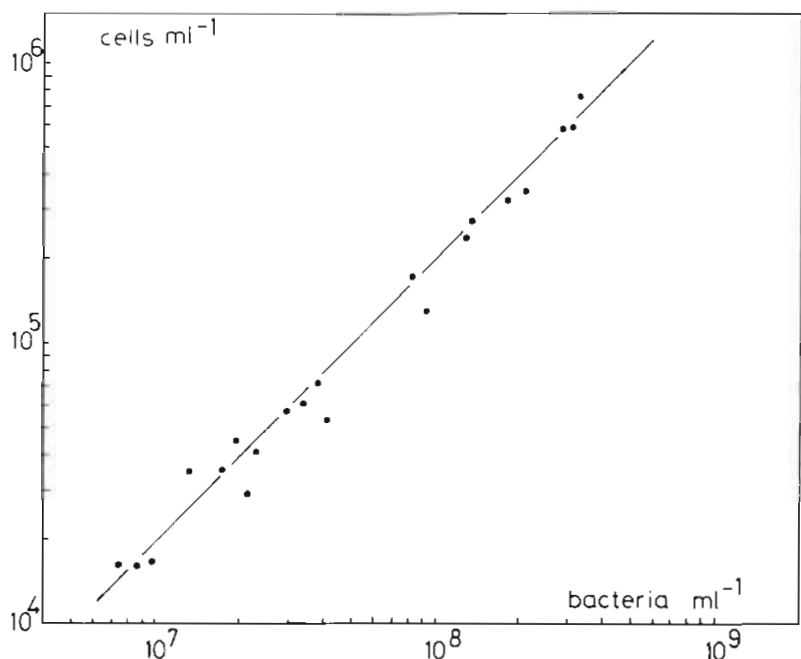

Fig. 8. Ochromonas sp. Cell yield as function of initial bacterial concentration

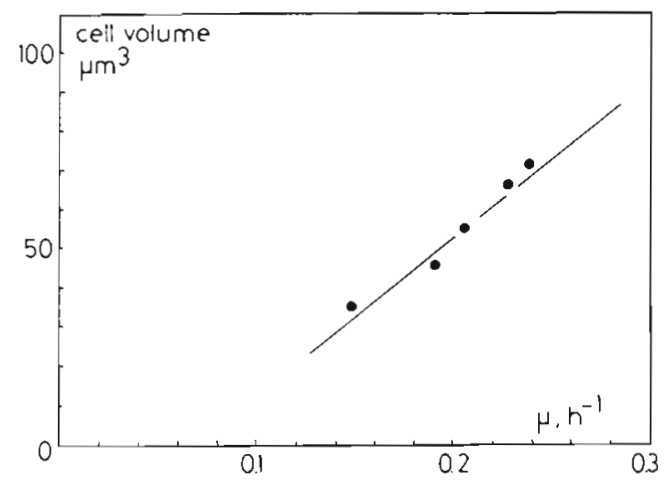

Fig. 9. Actinomonas mirabilis. Cell volume as function of exponential growth rate

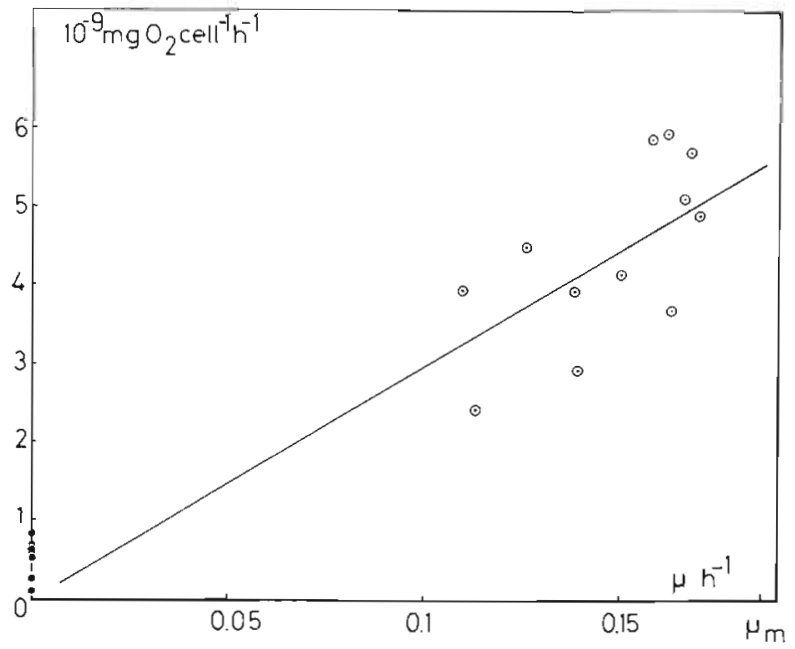

Fig. 10. Ochromonas sp. Oxygen consumption in cultures with different growth rates. Dotted circles: starving cells

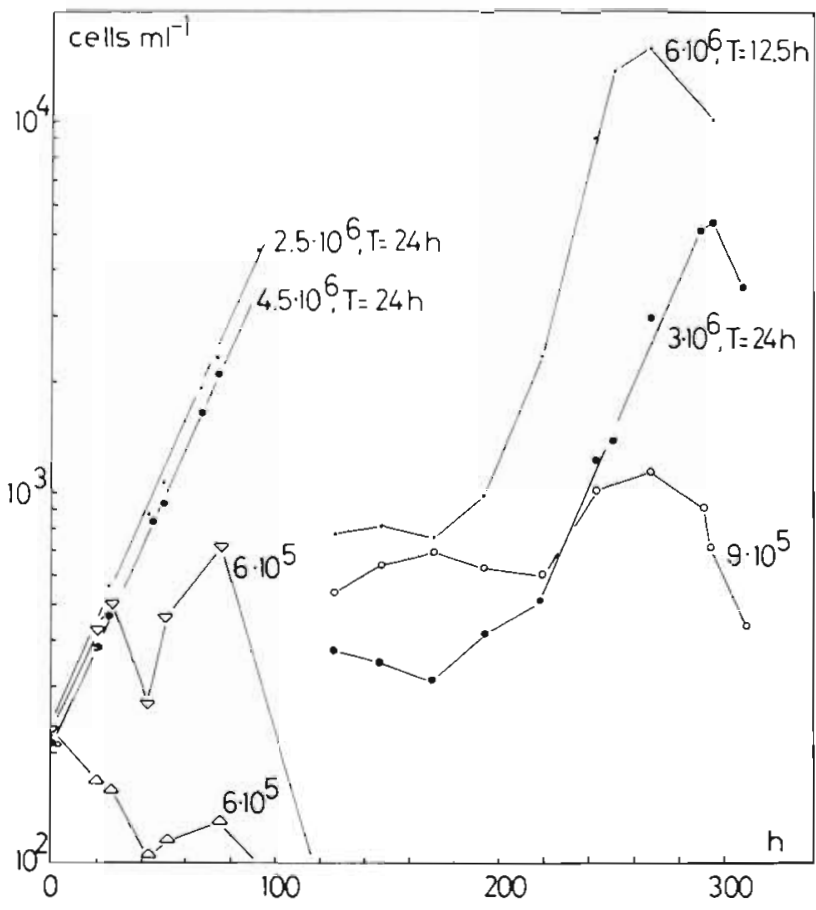

Fig. 11. Ochromonas sp. Behaviour of 7 cultures initiated with low bacterial concentration. For each curve initial bacterial concentration and doubling time is indicated

generations had a volume proportional to growth rate. However, this relationship could only be established for fairly rapidly growing cells ( $\mu$ : 0.15 to $\left.0.25 \mathrm{~h}^{-1}\right)$ due to the inherent difficulty of following slow balanced growth in batch cultures (Fig. 9).

Respiration was measured in Ochromonas sp. (Fig 10) and Pleuromonas jaculans in a number of cultures with different growth rates and for starving cells. When food supply is exhausted, respiration rate per cell declines until it eventually reaches 2 to $4 \%$ of the rate characteristic of exponential growth. This is discussed in Fenchel (1982 b). During exponential growth, a linear relation between growth rate and respiration could be expected (since $\mu$ is proportional to $U$ ); this is not contradicted by the data in Fig. 10. At growth rates approaching $\mu_{m}$, the respiration rates of Ochromonas sp. and $P$. jaculans are 5.0 and $1.9 \times 10^{-9} \mathrm{mg} \mathrm{O}_{2}$ cell $^{-1}$ $\mathrm{h}^{-1}$. The carbon contents of the 2 forms (post growth cells) are 1.8 and $0.75 \times 10^{-8} \mathrm{mg}$ cell ${ }^{-1}$ respectively.

Attempts to follow slow growth in batch cultures are difficult; only very small inoculates can be used and the long duration of the experiments may lead to loss of control of the cultures (recycling of undigested bacterial remains and of dead flagellates, loss of nutritional value of the live bacteria). Attempts to follow slow growth were made for Ochromonas sp. (Fig. 11). These experiments indicate that the flagellate can maintain a steady state growth at least as slow as $0.028 \mathrm{~h}^{-1}$ at 
Table 1. Basic parameters of growth and feeding at $20^{\circ} \mathrm{C}$

\begin{tabular}{|c|c|c|c|c|c|c|c|c|c|c|}
\hline Species & $\begin{array}{c}\text { Aprox. } \\
\text { growth } \\
\left(\mu \mathrm{m}^{3}\right)\end{array}$ & $\begin{array}{l}\text { olume } \\
\text { starv. } \\
\left(\mu \mathrm{m}^{3}\right)\end{array}$ & $\begin{array}{l}\text { Max. cle } \\
\left(\mathrm{ml} \mathrm{h}^{-1}\right)\end{array}$ & $\begin{array}{r}\text { earance } \\
\left(h^{-1}\right)\end{array}$ & $\begin{array}{l}\text { Max. uptake } \\
\left.\text { (bact. } h^{-1}\right)\end{array}$ & $\underset{\left(h^{-1}\right)}{U_{m}}$ & $\begin{array}{l}\text { Yi } \\
\text { observed } \\
\text { (cells } \\
\text { bact }^{-1} \text { ) }\end{array}$ & $\begin{array}{l}\text { corrected } \\
\text { (cells } \\
\text { bact }^{-1} \text { ) }\end{array}$ & $\begin{array}{l}\text { Yield } \\
(\% \text { C })\end{array}$ & $\begin{array}{c}\text { Net. ass } \\
(\% \text { C) }\end{array}$ \\
\hline Monosigasp. & 20 & 5 & $2.0 \times 10^{-6}$ & $9.8 \times 10^{4}$ & 27 & 0.17 & $2.5 \times 10^{-2}$ & $6.2 \times 10^{-3}$ & & \\
\hline Paraphysomonas vestita & 190 & 80 & $1.7 \times 10^{-5}$ & $9.1 \times 10^{4}$ & 254 & 0.23 & $1.8 \times 10^{-3}$ & $9.1 \times 10^{-4}$ & & \\
\hline Actinomonas mirabilis & 75 & 40 & $7.9 \times 10^{-5}$ & $1.1 \times 10^{6}$ & 107 & 0.25 & $4.5 \times 10^{-3}$ & $2.3 \times 10^{-3}$ & & \\
\hline Ochromonas sp. & 200 & 100 & $1.0 \times 10^{-5}$ & $5.2 \times 10^{4}$ & 190 & 0.19 & $2.0 \times 10^{-3}$ & $10^{-3}$ & 34 & 59 \\
\hline Pleuromonas jaculans & 50 & 25 & $1.4 \times 10^{-6}$ & $5.5 \times 10^{4}$ & 54 & 0.16 & $6.0 \times 10^{-3}$ & $3.0 \times 10^{-3}$ & 43 & 60 \\
\hline Pseudobodo tremulans & 90 & 20 & $1.0 \times 10^{-5}$ & $1.1 \times 10^{5}$ & 84 & 0.15 & $7.1 \times 10^{-3}$ & $1.8 \times 10^{-3}$ & & \\
\hline
\end{tabular}

bacterial densities of around $2 \times 10^{6} \mathrm{ml}^{-1}$. Since Ochromonas sp. (together with Pleuromonas jaculans) had the lowest clearance measured (Table 1), it is likely that other forms studied would grow with doubling times of ca. $24 \mathrm{~h}$ at bacterial densities 2 to 4 times lower; for example, Actinomonas mirabilis still grows with doubling every $4.6 \mathrm{~h}$ at bacterial concentrations of around $2 \times 10^{6} \mathrm{ml}^{-1}$ (Fig. 5).

Table 1 summarizes the parameters of growth for the studied species. Cell volumes are given for rapidly growing cells as well as for post growth cells, and clearances are given as $\mathrm{ml} \mathrm{cell}{ }^{-1} \mathrm{~h}^{-1}$ and also in units of cell volume $\mathrm{h}^{-1}$. It is seen that the maximum consumption rate $\left(U_{m}\right)$ correlates with cell volume. Since the food bacteria measure about $0.6 \mu \mathrm{m}^{3}$, the studied forms can engulf about $60 \%$ of their own volume $\mathrm{h}^{-1}$. Cell yield is inversely related to cell volume; about $30 \%$ of the engulfed bacterial volume reappears as flagellate volume. Values of $\mu_{\mathrm{m}}$ fall within a range corresponding to minimum doubling times between 2.8 and $4.6 \mathrm{~h}$. In the case of Ochromonas sp. and Pleuromonas jaculans, yields (gross growth efficiencies) in terms of organic $C$ were found to be 34 and $43 \%$ respectively. Assuming an $R Q$ of 1 , net growth efficiencies are about $60 \%$ for both forms. Consequently about 43 and $28 \%$ of the ingested bacterial food is egested in the 2 forms respectively.

Clearance values varied considerably among the studied species ranging from about $5 \times 10^{4}$ to $10^{6}$ (body volumes) $\mathrm{h}^{-1}$. Half saturation constants, $K$, can be calculated from Table 1 as $U_{m} / F_{m}$ and fall within the range $1.32 \times 10^{6}$ Actinomonas mirabilis) to $3.8 \times 10^{7}$ (Pleuromonas jaculans) bacteria $\mathrm{ml}^{-1}$.

\section{DISCUSSION AND CONCLUSIONS}

The fact that yield is constant within the range of growth rates studied shows that the energy required for growth (macromolecular synthesis) totally dominates the energy budget of growing cells and that 'maintenance energy' must be a very small fraction.
Indeed, maintenance energy may be a somewhat elusive concept in microorganisms in which a zerogrowth' condition may not be a physiological possibility so that below a certain resource level, the organisms change from a state of slow growth to one adapted to survival during a period of starvation (Fenchel, 1982 b). The fact that cell yield does not change with growth rate in bacteria and yeasts is well known (Payne, 1970) and this is also nearly true for larger protozoans (Curds and Cockburn, 1968). It is mainly a property of small-sized organisms. One reason is that mechanical energy constitutes a diminishing fraction of the entire power output of a microorganism; thus for Ochromonas sp. it can be shown that the flagellar activity can only account for about $1 \%$ of the energy budget of a growing cell and this figure may increase to about 2 to $5 \%$ for a cell starved for several days (Fenchel, in preparation).

Other results reported in Table 1 are not surprising. A net growth efficiency in terms of $C$ of about $60 \%$ has been found for bacteria (growing on organic compounds with an oxidation level of $\mathrm{C}$ as in glucose) as well as in eukaryote cells (Payne, 1970; Calow, 1977). Maximum food consumption, in all cases some $60 \%$ of the cell volume $\mathrm{h}^{-1}$, is somewhat lower than in small ciliates which may well engulf more than $100 \%$ of the body volume $\mathrm{h}^{-1}$ (Fenchel, $1980 \mathrm{a}$ ).

The variation in clearance rate among the studied species is probably in 2 ways related to differential adaptations to food particle size; in the present study only 1 size and shape of food particles was offered. Two of the species, Monosiga sp. and Actinomonas mirabilis are regular filter feeders; for particles retained $100 \%$, clearance should equal filter area $\mathrm{x}$ water velocity, and this roughly holds (Fenchel, 1982 a). However, in A. mirabilis the mutual distance between adjacent pseudopodia forming the filter is about $1 \mu \mathrm{m}$ proximally growing to about $3.5 \mu \mathrm{m}$ distally, so while the flagellate is efficient with respect to the test bacteria it is probably leaky with respect to small bacteria (ca. $0.5 \mu \mathrm{m}$ ) which dominate natural bacterioplankton. In Monosiga sp., on the other hand, 
the filter organelle has a much lower porosity $(0.25$ to $0.35 \mu \mathrm{m})$ and will retain even the smallest prokaryote cells. As shown in Fenchel (1982 a) the water velocity trough the filter is much lower in Monosiga sp. than in A. mirabilis and this may be related to the increasing pressure drop resulting from decreased porosity (Fenchel, $1980 \mathrm{c}$ ). This explains the difference in the clearance measured in the 2 forms, but the relative performance of the 2 forms will to a large extent depend on the size composition of bacterial cells in nature. The other 4 types of flagellates depend on direct impact with food particles transported by the feeding currents. It is very difficult to model how clearance depends on cell morphology and water velocity. However, general considerations indicate that clearance will be proportional to the square of food-particle diameter and that specific clearance must decrease strongly with predator size (Fenchel, 1982 a). Besides showing that this form of feeding is only efficient if the size difference between prey and predator is not too large, the considerations show that clearance will depend strongly on food particle diameter for any given flagellate species. The clearances given in Table 1 may therefore not reflect clearance in nature which will always depend on the available particle spectrum.

In general, the specific clearances are some 10 to 50 times higher than those found in bacterivorous ciliates (but comparable to those reported from ciliates feeding on larger particles) and suggest the importance of smaller protozoans rather than ciliates as bacterial consumers in marine plankton (Fenchel, 1980 b). The parameter values found in the present study indicate that flagellates of the type studied may just be capable of growing at bacterial densities $\left(0.5-2 \times 10^{6} \mathrm{ml}^{-1}\right)$ actually found in marine plankton and may be responsible for the maintenance of this level although it has to be kept in mind that the average bacterial size in marine plankton is smaller than the cells used in the study.

\section{LITERATURE CITED}

Calow, P. (1977). Conversion efficiencies in heterotrophic organisms. Biol. Rev. 52: 385-409

Chretiennot, M.-J. (1974). Nanoplancton de flaques supralittorales de la région de Marseille. Protistologica 10: $477-488$
Curds, C. R., Cockburn, A. (1968). Studies on the growth and feeding of Tetrahymena pyriformis in axenic and monoxenic culture. J. gen. Microbiol. 54: 343-358

Curds, C. R., Cockburn, A. (1971). Continuous monoxenic culture of Tetrahymena pyriformis. J. gen. Microbiol. 66: 95-108

Fenchel, T. (1980 a). Suspension feeding in ciliated protozoa: functional response and particle size selection. Microb. Ecol 6: 1-11

Fenchel, $\Upsilon$ (1980 b). Suspension feeding in ciliated protozoa: feeding rates and their ecological significance. Microb. Ecol. 6: 13-25

Fenchel, T. $(1980 \mathrm{c})$. Relation between particle size selection and clearance in suspension-feeding ciliates. Limnol. Oceanogr. 25: 733-738

Fenchel, T. (1982 a). Ecology of heterotrophic microflagellates. I. Some important forms and their functional morphology. Mar. Ecol. Prog. Ser. 8: 211-223

Fenchel, T. (1982 b). Ecology of heterotrophic microflagellates. III. Adaptations to heterogenous environments. Mar. Ecol. Prog. Ser. 9: in press

Fenchel, T. (1982 c). Ecology of heterotrophic microflagellates. IV Quantitative occurrence and importance as consumers of bacteria. Mar. Ecol. Prog. Ser. 9: in press

Ferguson, R. L., Rublee, P. (1976). Contribution of bacteria to the standing crop of coastal plankton. Limnol. Oceanogr. 21: $141-145$

Haas, L. W., Webb, K. L. (1979). Nutritional mode of several non-pigmented microflagellates from the York River Estuary, Virginia. J. exp. mar. Biol. Ecol. 39: 125-134

Hagströ, \&, Larsson, U., Hörstedt, P., Normark, S. (1979). Frequency of dividing cells, a new approach to the determination of bacterial growth rates in aquatic environments. Appl environ. Microbiol. 37: 805-812

Hobbie, J. E., Daley, R. J., Jasper, S. (1977). Use of Nuclepore filters for counting bacteria by fluorescence microscopy. Appl environ. Microbiol. 33: 1225-1228

Hoppe, H. G. (1976). Determination and properties of actively metabolizing heterotrophic bacteria in the sea, investigated by means of micro-autoradiography. Mar. Biol. 36: 291-302.

Lighthart, B. (1969). Planktonic and benthic bacteriovorous protozoa at eleven stations in Puget Sound and adjacent Pacific Ocean. J. Fish. Res. Bd Can. 26: 299-304

Payne, W. J. (1970). Energy yields and growth of heterotrophs. A. Rev. Microbiol. 24: 17-52

Pomeroy, L. R., Johannes, R. E. (1968). Occurrence and respiration of ultraplankton in the upper 500 meters of the ocean. Deep Sea Res. 15: 381-391

Sieburth, J. (1979). Sea microbes, Oxford University Press, New York

Sorokin, Yu. I. (1977). The heterotrophic phase of plankton succession in the Japan Sea. Mar. Biol. 41: 107-117

Strickland, J. D. H., Parsons, T. R. (1965). A practical handbook of seawater analysis. Fish. Res. Bd Canada 167 : $1-311$ 